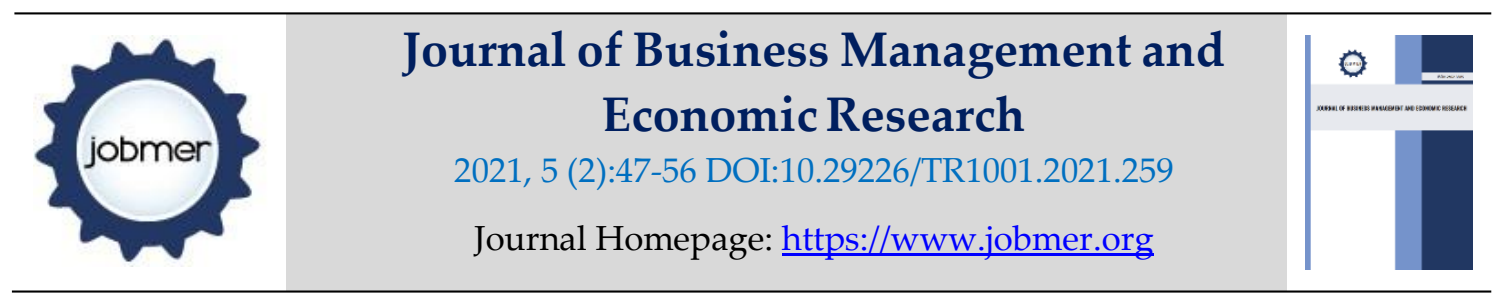

\title{
Factors Affecting Household Income Among Motorcycle Operators. A Case of Embu County Residence, Kenya
}

\author{
Gitonga Veronica Wawira*, \\ Department of Economics \\ Moi University \\ ${ }^{*}$ Corresponding Author: veromu@yahoo.com \\ Ernest Saina \\ Department of Economics \\ Moi University \\ Koech Ronald \\ Department of Economics \\ Pwani University
}

\begin{abstract}
Kenya's population is predominantly youth with the age group of 15-35 years accounting to approximately $38 \%$ of the total population and lack of jobs is the single largest concern of Kenyans. Statistics show that more than 800,000 Kenyan youth enter the job market each year but only $10 \%$ of those jobs are in the formal sector while those of informal sector such as boda-boda operators are not fulltime or remunerative. However, a socio-economic benefit of the boda-boda industry is the considerable direct and indirect income generating opportunities it creates. The aim of this study was to highlight and determine some of the key factors that affects rural household income in case study of Embu county residence. These factors are age, marital status, education level of the motorcyclist. Other factors include the training, experience. Ownership as well as maintenance costs. Results found indicated that no significant relationship between demographic characteristics (age, marital status, education level) and motorcycle ownership on rural household income whereas training, experience and maintenance costs significantly affects daily income. Based on this result, the study concludes by stating that a motorcycle which was traditionally intended for private use, have been appropriated for a commercial activity as the motorbike taxi and has been a source of livelihood to many Kenyans. The commercial use of motorcycle can be explained by the combination shortage of transport supply, availability of factors of production and deficiencies in the regulatory framework and the enforcement of regulations.
\end{abstract}

Keywords: Motorcycle, Rural Household, OLS, Kenya. 


\section{Background Information}

Kenya youth unemployment is a serious development issue (Gladys, 2013). It is estimated that $64 \%$ of unemployed persons in Kenya are youth. Interesting only $1.5 \%$ of the unemployed youth have formal education beyond secondary school level and the remaining over $92 \%$ have no vocational or professional skills training. This group idle all day long, others get into crime while others try anything else to make ends meet. According to economic survey 2010, the total number of units (vehicles) registered on 32.8 percent increase to stand at 161813 in 2009. The increase is mainly attributed to higher registration of motor and auto cycles which rose significantly accounting for 56.3 percent of total registered units. Motorcycles and auto cycles have become popular across the country. In rural areas they have provided relief to limited transport options while in the urban areas they have supplemented both passenger transport and mail delivery GOK (2010). In Kenya majority of the boda-boda riders do not have another form of employment after the zero rating of all motorcycles below $250 \mathrm{cc}$, the motorcycles prices went down. Therefore, for some motorcycles became an opportunity to get into the lucrative transport business. Many bought the motorbikes for their children or brothers to do business with. Others bought these motorbikes and hired the idle youth to do business with it and give them a certain amount of money at the end of the day Gladys (2013).

According to MTP (2017-2019), road transport in Kenya is faced by: "Congestion in Cities and Urban areas; increased use of 'Boda Boda' on roads raising safety concerns; lack of harmonization of cross border transport regulations and operational procedures; rapid urbanization and increased traffic volume; conflicting legislations e.g. the Roads Act, 2007 and the Local Government Act, CAP 265; lack of specific standards for county roads; huge maintenance backlog of the road network; weak enforcement of axle load rules and regulations; high cost/delays in relocation of utilities and services along and across road reserves; high cost of road construction; and disproportionate/mode of transport imbalance."

\section{Literature Review}

Tuan and Shimizu (2005) in their study in Hanoi city Vietnam on household motorcycle ownership behavior, using a retrospective survey to collect household motorcycle transaction process, while heterogeneity was analyzed using random coefficient logit model, the results showed that increases in number of workers or students, motorcycle price, income, and previous transactions significantly influence current transaction decision and that sufficient high taxes imposed on motorcycle users could be effective in controlling the ownership. In another study, HSU, and Lin (2007) in Taipei Taiwan investigated both car and motorcycle ownership with 336 samples using multinomial logit model. The study assumed that when both a car and a motorcycle are owned by the same household each have a relation of substitution. The study concluded that the main reason for motorcycle and a car increase car ownership between 12\% - 29\% and while it reduces motorcycle ownership.

Sadullah et al., (2007) conducted a study in Penang, Malaysia using multinomial logit model to examine motorcycle ownership. They affirm that total monthly household income, car ownership, total number of driving licenses in the household and number of household members influenced motorcycle ownership. The study concludes that motorcycle will remain the mode of transport soon, particularly in the group of low- and middle-income households. According to Howe and Lyiola (1996) stated earnings for motorcycles operations differ for owners and hirers and by location. Because of small sample sizes not too much significance can be read into the differences. Owner earnings in Kampala are almost double those of hirers but they do have additional costs especially 
vehicle depreciation and major repairs. Peri-urban areas yield substantially lower earnings for owners per week but contrary to logic hirers appear to earn more per week.

Kimwetich et al., (2012) in their study to determine the level of compliance and awareness of traffic rules and regulations among operators in Kitui town, only $2.2 \%$ of the 90 motorcycle taxi operators knew traffic rules that governed their operations. The study revealed that $97.8 \%$ of all the respondents when asked to state traffic laws to be obeyed while on public roads gave sketch answers or never attempted to answer. In this study $57.8 \%$ of operators reported having a driving license leaving out a massive $42.2 \%$ without this vital document. The $42.2 \%$ operators were on the roads illegally and this is a demonstration of failure by the control and regulatory agencies in Kenya to enforce traffic laws and regulations

\subsection{Microeconomic Model}

The microeconomic model that was used in the study was developed by Kitov (2005). According to Kitov (2005) the principal assumption of the model is that every person above fifteen years of age (the official starting age for work) has a capability to work or earn money using some means, which can be a job, bank interest, stocks, among other activities. The model allows additional redistribution of the income inside households. The model does not allow anybody to survive without income. So, everybody older than 15 years of age has some positive income. The total amount of money a person earns is proportional to her/his capability to earn money, that is the model does not allow any difference between the amount of money earned by the person and the amount of money produced by the person.

The amount of money received by the person or the personal income is exactly equal to the amount of money (or total price) the person had produced for the outer world in form of goods and/or services. In this case, the total sum of all the personal incomes in the country is exactly equal to the country's GDP. It also means that there is no other source of the personal income except the working age population (all people above 15 years of age). The person is not isolated from the surrounding world and the work (money) s/he produces dissipates (leaks) in the interaction with the outer world, decreasing the final income.

One can consider this dissipation process as related to the effects of the real (physical) world restricting capability to produce and concurrence with the people around who tend to diminish merits or price of the person's product. As in many physical models, the rate of the dissipation is proportional to the attained income level and inversely proportional to the size of the means used to earn the money. One can write a simple balance equation for a person earning money:

On the whole, two main driving forces of our model are similar to those in the Cobb-Douglas production function: $Y=L^{a} K^{b}$, where $Y$ is the measure of production (e.g., Gross Domestic Product) in a given country, which may be measured in the country-specific currency, $L$ is the labor often considered as work hours, $K$ is the physical (or work) capital (e.g., machinery, equipment, buildings, hardware, software, among others), and $a$ and $b$ are the output elasticities (Warr, B., \& Ayres, R. U. (2012).

Specifically, labor is the only source of products measured in money, and thus, the only source of income. At the same time, using larger and more efficient work instruments people produce more goods and services, also in terms of their real value measured in money units. This consideration is 
fully applicable at the level of individual production. All persons of working age are characterized by nonzero (and varying) capabilities to generate income and use work instruments of different sizes to do that.

Unfortunately for economics, the Cobb-Douglas function is a non-physical one. It implies the unlimited growth in GDP because it does not include any forces counteracting the production process. Following the physical approach discussed in Section 1.1, it is assumed that no person is isolated from the surrounding world. When a person starts her work the forces arise to counteract any production action. In this setting, the work (money) she produces must dissipate (devaluate) through the entire diversity of interactions with the outside world, thereby decreasing the final income per unit time. All counteractions with outer agents, which might be people or some externalities, determine the final price of the goods and services the person produces

\section{Results}

Age of the Respondents-Majority of the motorcycle operators were between the ages of 21 and 30 years and it accounted for at least 42.1 percent followed by those between the ages of 31 and 40 at 35.3 percent. This shows that most of the boda-boda operators are either middle aged or in their 20's. A few who were under the age of 20 at 8.2 percent. This could be attributed to the fact that most youths in this age bracket are still in school. In Niamey, the users of private motorbikes are mainly young male middle-income earners, while in Douala the clientele of motorbike taxis consists of young working poor (Porter, G., Abane, A., \& Lucas, K. 2020). The boom in the use of motorbike taxis is also since they meet travel needs not satisfied by the other public transport modes, such as trips or segments of trips that are simultaneously too long to be made on foot and too short to represent a profitable market for other public transport modes. In both cities, attitudes towards personal and commercial motorbikes vacillate between prizing the flexibility of usage and rejecting its dangers. The most pressing needs for research into motorbikes, particularly taxis, relate to environmental, social, and public health issues, with a view to improving regulation of the activity.

Boda-boda business therefore provides a living mostly for young drivers between 18 and 35 years as also observed in Douala, West and Central Africa. This is due to the fact that it is a youthful age, and the operators are able to perform their duties well since the energy (for instance to wake up early and sleep late) is there. The SLAM survey data (2001) concurs well with this as it birthed the often- alleged 'youth' of boda-boda. Table 1 presents the results on age. These finding parallels those of Bello et al., (2017) that states that commercial motorcycle enterprise is a youth dominated activity, since majority of the participants in Gombe State, Nigeria were in the age bracket of 21 - 30 years and depended on it to sustain their young families. Therefore boda-boda activities are regarded as a reserve for the young and energetic individuals in Embu County.

Marital Status of the Respondents- Marital status of respondents was also analyzed and from the findings, the proportion of the respondents married was higher to the single one. Out of the 354 respondents, 212 (59.9 percent) were married while 140 (39.5 percent) were single, other categories 2 (0.6 percent). This is because they wake up exceedingly early to cater for early morning clients and close their business late after serving evening clients, which is possible if one has a partner to help perform other home duties.

It can also mean that the boda-boda operators' direct contact with many people exposes them to friendships and partnerships leading to marriage. Furthermore, the leading age category is $21-30$ 
Journal of Business Management and Economic Research (JOBMER), Vol.5, Issue.2, pp.47-56

years which fits under the marriage age. This was in tandem with previous study by Gboyega et al., (2012) that motorcycle business is dominated by married individuals since they have extra responsibilities of providing necessities for their families

Level of Education of the Respondents- Among the 354 motorcycle operators 275 (77.70\%) of them had only KCPE/CPE certificates. This was followed by those with KCSE/KACE certificates at 65 (18.4\%). At this low level of education, employability rate is low especially for school dropouts. The graduate proportion was insignificant being only $1.4 \%$. Mostly, a boda-boda operator has the popular image of a poor persons 'school dropout' job which is supported by World Health Organization (2016) conducted a study on the use of motorcycles in developing countries and observed that although the problem affects all countries, it should be noted that $88 \%$ of the worldwide fleet of powered two- and three-wheelers is found in low- and middle-income nations, and more than $90 \%$ of the deaths of motorcycle users occur in these countries. WHO (2016) study cited that in these countries, motorcycles have a dual purpose for users, who are typically between 15 and 34 years of age. First, they facilitate the movement of goods and people. Second, they are often part of a business or a source of income. In many cases they are used for commercial purposes, primarily as taxis or delivery vehicles. The study further explained in poorer regions, entire families get around on motorbikes. In developing countries most victims are young adults, while in high-income countries motorcycle fatalities occur among slightly older people.

Rural Household Income- The outcome variable was rural household income. This variable was measured using income per day (daily gross earning). The daily gross earning was used since it is more appropriate given that boda-boda activity is a daily paid activity (Arosanyin, 2010; Arosanyin \& Ipingbemi, 2007). There were other minor indicators of rural household income such as amounts of payments received, rate of payment, nature of road infrastructure and income from the occupation business before joining boda-boda business. The results obtained showed that most of the operators earn on average between Kshs. 600 and Kshs. 1000 per day. This constitutes $60.2 \%$ of the sample. Only $2.5 \%$ of the operators can earn less than Kshs.500 per day. $37.3 \%$ of the operators earn more than Kshs. 1000 per day. The study is in support with studies by the World Bank which observed that the boda-bodas result in a significant increase in income to those lucky enough to own or operate them. They give a boost to local trading and service economies and directly create secondary employment. According to National Forum Group (1996) boda-boda enterprise has become a popular industry towards the provision of informal self-employment and income generating opportunities for many unemployed youths thus changing the face of rural-urban transport services in Kenya

Training- From Table 1, it was established that that majority ( $n=275,77.68$ percent) of the motorcycle operators have been trained while 79 (22.32 percent) have not been trained. This finding of higher percentage contradicts Musilimu and Oluwole (2014) and Gbagir, Etu and Oyedepo (2018) both studies done in Nigeria that documents that most of the respondents learnt to motorcycles in an informal way and in most cases received little or no formal training.

Ownership - For motorcycle ownership it was found out that majority $(n=202,57.07$ percent) were owners of motorcycles. This implies that majority of the motorcycle operators prefer their own motorcycles which implies that are self-employed hence, will own all the income generated and thus implies higher disposable income as compared to those who are hired who must remit part of the income to the owners of the motorcycles. This corroborates with previous study by Gumel, Adam \& Rilwan (2017) who found out that majority of motorcycle operator prefer their own motorcycles. 
Those in partnership were 114 (32.55 percent) and this was followed by those who were employed by others at 36 (10.17 percent) and the least were those who were not on any of the above categories at 2 (0.21 percent).

Experience- On experience, high number of motorcycle operators, 173 (48.81 percent) had experience of 4 years and this could be due to unemployment in the country, this was followed by those with experience of 3 years with 124 (35.0 percent). Those with experience of 5 years and above were 50 (14.13 percent) while the least group had 7 respondents (2.00 percent).

Maintenance Cost-On maintenance cost, majority of the motorcycle operators spent approximately Kshs 1000-3000 per month, 215 (60.78 percent). This was followed by those who spent. Those who spent between Kshs 1000 and Kshs 3000 were while those spent Kshs less than Kshs 1000 were 100 (28.25 percent) and those who spent between Kshs 3000 and 500 were 29 (8.19 percent) and the least category are those spent above Kshs 7000 who were 10 (2.83 percent).

Table 1. Descriptive Results for Demographics

\begin{tabular}{|c|c|c|c|}
\hline Variable & Category & Frequency & Percent \\
\hline \multirow{4}{*}{ Age of respondent } & Below 20 & 29 & 8.20 \\
\hline & $21-30$ & 149 & 42.10 \\
\hline & $31-40$ & 125 & 33.30 \\
\hline & $41-50$ & 51 & 14.40 \\
\hline \multirow{3}{*}{ Marital Status } & Married & 212 & 59.90 \\
\hline & Single & 140 & 39.50 \\
\hline & Other Categories & 2 & 0.60 \\
\hline \multirow{5}{*}{ Level of Education } & University & 5 & 1.40 \\
\hline & ‘A’ Level (KACE) & 8 & 2.30 \\
\hline & ‘O' Level KCSE/KCE & 65 & 18.40 \\
\hline & КСРЕ/С.P. Е & 275 & 77.60 \\
\hline & Any Other & 1 & 0.30 \\
\hline \multirow{3}{*}{ Rural Household Income } & Less than Kshs 500 & 9 & 2.5 \\
\hline & Kshs 600 - 1000 & 213 & 60.2 \\
\hline & Above Kshs 1000 & 132 & 37.3 \\
\hline \multirow[t]{2}{*}{ Training } & Yes & 234 & 66.10 \\
\hline & No & 120 & 33.90 \\
\hline \multirow{4}{*}{ Experience } & 2 Years & 7 & 2.00 \\
\hline & 3 Years & 124 & 35.00 \\
\hline & 4 Years & 173 & 48.87 \\
\hline & 5 Years and above & 50 & 14.13 \\
\hline \multirow[b]{2}{*}{ Ownership } & Your own & 202 & 57.07 \\
\hline & Employed & 36 & 10.17 \\
\hline \multirow{6}{*}{ Maintenance Cost } & Partnership & 114 & 32.55 \\
\hline & Any other & 2 & 0.21 \\
\hline & Less than Kshs1000 & 100 & 28.25 \\
\hline & Kshs 1000-3000 & 215 & 60.73 \\
\hline & Kshs $3000-5000$ & 29 & 8.19 \\
\hline & Above Kshs 7000 & 10 & 2.83 \\
\hline
\end{tabular}

Source: Authors Survey Data, 2021 
Regression Results-Ordinary least squares model was used to estimate and find out the significant factor influences of the explanatory variables on the rural household income. Table 2 shows that training, experience, and the maintenance cost negatively affected the daily household income while age, marital status, education level and ownership did not show any significant effects. We can say that income generated on operating a motorcycle in this region does not necessarily depend on the demographic characteristics but rather depends on the professionalism that is being trained, having experience as well as the cost of operation (maintenance cost).

The negative relation between professionalism (training) and household income in this region, could be associated by the fact that training incurs some costs and that majority of them have no professional training. Training in this case contradicts the idea that training enhances skills such as highway codes and traffic rules which helps them to handle and interpret their respective services and any other emerging issues. However, the negative finding supports the past studies by Luchidio, Kahuthia Gathu \& Gatebe (2013) who found out that training and incomes of motorcycle are negatively related because they may not have access to major towns because of friction between motorcycle operators and law enforcers. This may attribute to the fact that the focused the impact of training on safety status, thus the study overlooked the economic impact of training. Experience indicated a negative and significant coefficient because the longer the time the motorcycle stays in the industry gathers knowledge and helps him or her to gather and better skills such as building connection with customers that contributes to increased incomes and in results ventures into another business opportunities. This is tandem with previous study by Greve (2003). Operators with high maintenance costs are more likely not to set up economic activities compared to those with low maintenance costs. This is because they have extra costs, and this limits them to invest since there they have high overhead charges. Operates who renew their licenses more frequently are almost twice as likely to open other business activities compared to those to who renew less frequently.

Table 2. OLS Regression Results

\begin{tabular}{|c|c|c|c|c|c|c|}
\hline Source & SS & df & MS & & No. of Obs & $=354$ \\
\hline Model & 17.2663 & 7 & 2.4666 & & $\mathrm{~F}(7,346)$ & $=10.54$ \\
\hline Residual & 80.9964 & 346 & 0.2341 & & Prob $>$ F & $=0.000$ \\
\hline Total & 98.2627 & 353 & 0.2784 & & R-Squared & $=0.1757$ \\
\hline & & & & & Adj-R-Squared & $=0.1590$ \\
\hline & & & & & Root MSE & $=0.4838$ \\
\hline $\begin{array}{l}\text { Rural Household } \\
\text { Income }\end{array}$ & Coef. & Std. Err & $\mathbf{t}$ & $\mathbf{P}|\mathbf{t}|$ & \multicolumn{2}{|c|}{ [95\% Confidence Interval] } \\
\hline Age & -0.0252 & 0.0355 & -0.71 & 0.478 & -0.0951 & 0.0446 \\
\hline Marital status & 0.0500 & 0.0598 & 0.84 & 0.404 & -0.0677 & 0.1677 \\
\hline Education level & -0.0291 & 0.0456 & -0.64 & 0.524 & -0.1187 & 0.0605 \\
\hline Training & -0.2440 & 0.0622 & -3.92 & 0.000 & -0.3664 & -0.1217 \\
\hline Experience & -0.1138 & 0.0450 & -2.53 & 0.012 & -0.2024 & -0.0252 \\
\hline Ownership & -0.0663 & 0.0474 & -1.40 & 0.163 & -0.1596 & 0.0269 \\
\hline Maintenance cost & -0.1551 & 0.0439 & -3.53 & 0.000 & -0.2414 & -0.0687 \\
\hline Constant & 3.972 & 0.2819 & 13.73 & 0.000 & 3.3175 & 4.4265 \\
\hline
\end{tabular}

Source: Survey Data, 2021 


\section{Conclusions}

The current study has highlighted several important results. The boda-boda operation is a source of employment, livelihood and income generating activity among the youths in Embu, County. These findings highlight the importance of this informal transport sub-sector in the labor absorption process in the urban and rural sector in Embu, County. The analysis of earnings carried out reveals that majority of boda-boda operators are earning between Kshs 600-1000 (the current minimum wage in Kenya), and thus such earnings has made this informal sector to be attractive to many educated who would otherwise remain openly unemployed. In several Sub-Saharan African cities, a motorcycle which are traditionally intended for private use, have been appropriated for a commercial activity as the motorbike taxi. The commercial use of motorized two-wheelers can be explained by the combination of three factors: shortage of transport supply, availability of factors of production and deficiencies in the regulatory framework and the enforcement of regulations.

\section{Recommendations}

First, this study recommends that both county and national government should organize regular training for motorcycle operators on customer care, safety, and precaution. Secondly, it is further recommended that the government should set up an enabling business environment that should help boda-boda operators minimize their operational costs. This can be done by proper legislation that regulates while at the same time promote the informal transport services. Finally, In Embu County (a local economy) where employment opportunities are scarce, boda-boda transport sub-sector, a labor-intensive activity has become an alternative job opportunity for the unemployed. Thus, transport policies should be set to improve efficiency of the sub-sector in line with being part of comprehensive poverty alleviation policies. 
Journal of Business Management and Economic Research (JOBMER), Vol.5, Issue.2, pp.47-56

\section{References}

Arosanyin, G. T. \& Ipingbemi, O. (2007). “Car Wash Service in Nigeria Road Transport System: Evidence from Ilorin." The Nigerian Journal of Economic and Social Studies 49(1): 45-64.

Arosanyin, G. T. (2010). Earnings from Commercial Motorcycle Operations in Ilirin, Nigeria: A Study on Determinants. Ghana Journal of Development Studies, Volume 7, Number 2

Bello H. Y., Jikan-Jatum, M. \& Inuwa, N., (2017). An Appraisal of Socio-Economic Impacts of Commercial Motorcycles in Gombe State, Nigeria. International Journal of Asian Social Science. Pg 480-488.

Gboyega, A., Ebijuwa, A. S., Oyetola, S. O., \& Akinola, J. O. (2012). Factors influencing high rate of commercial motorcycle accidents in Nigeria. American international journal of contemporary research, 2(11), 130-140.

Gladys, M. \& Nyachieo M (2013). Creating employment through transport; The youth and (bodaboda) in Kitengela, Kajiado County-Kenya.

Government of Kenya, (2010). Economic Survey. Government Printer, Nairobi.

Greve, A., \& Salaff, J. W. (2003). Social networks and entrepreneurship. Entrepreneurship theory and practice, 28(1), 1-22.

Gumel, G. B., Adam, I. M., \& Rilwan, I. A. (2017). Impact of Commercial Motorcycle Transport in Raising Income: Evidence from Jigawa State, Nigeria. CARD International Journal of Social Sciences and Conflict Management, 2(3).

Howe, J. \& S. Lyiola Oni (1996). Nigeria downsizes to motorbikes. Sustainable Transport Number 6, Summer. www.stdp.org.

Hsu T.P., \& Lin, Y.J. (2007). Multinomial Logit Model of motorcycle and Car Ownership in Taiwan. Proceeding of the Eastern Asia society for transportation studies,

Kimwetich, C. J., Kyalo, D.N \& Mulwa A. S. (2012). The influence of urban transport policy on the growth of motorcycles and tricycles in Kenya. University of Nairobi

Kitov, I. O. (2005a). A model for microeconomic and macroeconomic development. Working Study 05, ECINEQ, Society for the Study of Economic Inequality.

Kothari, C. (2004). Research Methodology: Methods and Techniques. 2nd edition. New Age International Publishers, New Delhi India.

Luchidio, M., Kahuthia-Gathu, R., \& Gatebe, E. (2013). Impact of training boda boda operators and safety status in Kakamega county, Kenya. International Journal of Advance Research, 1(9), 118.

MTP (Medium Term Plan), (2017-2019). Employment, Poverty and Economy.

Warr, B., \& Ayres, R. U. (2012). Useful work and information as drivers of economic growth. Ecological Economics, 73, 93-102.

Porter, G., Abane, A., \& Lucas, K. (2020). User Diversity and Mobility Practices In SubSaharan African Cities: Understanding The Needs Of Vulnerable Populations.

Musulimu, A. A. \& A. Oluwole (2014). The Level of Compliance of Commercial Motorcyclists to Traffic Rules on Urban Roads in South Western Nigeria. Journal of Education and Social Research 4(3) pp 345-351.

Sadullah, A. F. M., \& Leong, L.V. (2007). A Study on the Motorcycle Ownership: A case Study in Penang State, Malaysia. Proceeding of the Eastern Asia Society for Transportation Studies,

Saunders, P, M, Lewns, \& Thornhill, A. (2003). Research methods for business students (3 rd Ed) Prentice Hall (London). 
Journal of Business Management and Economic Research (JOBMER), Vol.5, Issue.2, pp.47-56

Terre, Blanche, M., Durrheim, K. \& Painter, D. (2006). Research in Practice. $2^{\text {nd }}$ edition. Cape Town: University of Cape Town Press.

Tuan, \& Shimizu (2005). Modeling of Household Motorcycle Ownership Behavior in Hanoi City. Journal of the Eastern Asia Society for Transportation Studies, 6, 1751-1765.

Wegner, T., (2000). Quantitative Methods for Marketing Decisions. Kenwyn: Juta

WHO, (World Health Organization) (2016). Measures to improve the safety of motorcycles riders. America.

Willis, J. W. (2007). Foundations of qualitative research: Interpretive and critical approaches. Thousand Oaks, CA: Sage Publications.

Yin, R. (2005). Case Study Research: Design and Methods (3rd edition). Thousand Oak: SAGE. 